\title{
Smoke alarm use: prevalence and household predictors
}

\author{
Ian Roberts
}

\begin{abstract}
Objective-To determine the prevalence of smoke alarm use among families with children and to identify household factors that predict the absence of a smoke alarm.
\end{abstract}

Design-Cross sectional analysis of data collected in the September and November 1995 Omnibus Survey, conducted by the Office of Population Censuses and Surveys in the UK.

Subjects-A random sample of British households. Interviews were completed with 4043 householders. The response rate was $78 \%$.

Results-29\% of British households do not have a smoke alarm and smoke alarms were absent in $20 \%$ of households with children under 15 years. A smoke alarm was absent in $41 \%$ of privately rented homes compared with $17 \%$ of owner occupied homes. Living in private rental accommodation was the strongest household predictor of the absence of a smoke alarm (odds ratio $=3 \cdot 25,95 \%$ confidence interval 1.94 to 5.42 ). Householders who had heard of National Fire Safety Week or the TV smoke alarm advertising campaign were significantly more likely to have a smoke alarm. The apparent effect of these campaigns was greatest in families with children.

Conclusions-Smoke alarm use has continued to increase but a substantial proportion of British homes still do not have smoke alarms. Homes at greatest risk of residential fire are the least likely to have an alarm. Health professionals may be able to increase smoke alarm use among families with children, by counselling families about the benefits of smoke alarms. They may also be effective in this regard by lobbying local councils, houseing associations, or private landlords to install alarms in all properties and by advocating for national legislation.

(Injury Prevention 1996; 2: 263-265)

Keywords: burns, fires, smoke alarms.

Department of Epidemiology, Institute of Child Health, University of London, 30 Guilford Street, London WC1N 1EH

Correspondence to: Ian Roberts.
In August 1995, five children, four from the same family, died of smoke inhalation after fire raged through their home on a North Wales council estate. ${ }^{1}$ Although five deaths in one fire in unusual, household fires nevertheless remain an important cause of childhood mortality. Each year in England and Wales an average of 69 children die in fires in the home. ${ }^{2}$ One of the most important risk factors for death in the event of a house fire is the absence of a smoke alarm (relative risk $=3.4,95 \%$ confidence interval (CI) $2 \cdot 1$ to $5 \cdot 6){ }^{3}$ Smoke alarms are particularly effective in preventing death when the fire involves young children. Over the past five years the proportion of British households with smoke alarms has increased substantially. In the 1992 British Crime Survey, $45 \%$ of householders said that they had a smoke alarm, compared with $8 \%$ in $1988 .{ }^{4}$ Although the increase is encouraging, there are still many homes without alarms. Increasing alarm use remains an important child health issue. We used data from a 1995 survey commissioned by the Home Office to examine the prevalence of smoke alarm use in the UK and to identify household factors that predict the absence of a smoke alarm.

\section{Methods}

At the request of the Home Office, questions on smoke alarm use were included in the September and November 1995 Omnibus Survey conducted by the Office of Population Censuses and Surveys. ${ }^{5}$ The sampling frame for the survey is the postcode address file of 'small users', which includes all private household addresses. A sample of 100 postal sectors is selected, stratified by region, the proportion of households renting from local authorities, and socioeconomic group. Within each sector, 30 addresses are randomly selected for the survey. Data on smoke alarm use and sociodemographic factors are collected using interviewer administered structured questionnaires. The present analyses are based on the combined data from the September and November surveys.

The relationship between household factors and smoke alarm absence was quantified using odds ratios (ORs) and $95 \%$ CIs. ORs greater than 1 indicate that the household characteristic in question increases the likelihood of a smoke alarm being absent, while those less than 1 indicate a decreased likelihood of a smoke alarm being absent. Logistic regression modelling was used to identify the household factors that independently predict that absence of a smoke alarm. Separate analyses were conducted for all households and for households with children under 15 years.

\section{Results}

A total of 4043 interviews were completed, a response rate of $78 \%$. Data on smoke alarm use were available for $4012(99 \%)$ households. There was no smoke alarm in $29 \%$ of households. Of the 4043 households surveyed, 
$30 \%$ had children younger than 15 years. Households with children were significantly more likely to have smoke alarms $(\mathrm{OR}=0.50$, $95 \%$ CI 0.43 to 0.59 ), being present in $80 \%$ of these households. Household predictors of smoke alarm use are shown in table 1 . Housing tenure was strongly associated with the absence of an alarm. Homes rented from private landlords were also substantially less likely to have a

Table 1 Household predictors of smoke alarm non-ownership

\begin{tabular}{|c|c|c|c|}
\hline \multirow[b]{2}{*}{ Variable } & \multicolumn{2}{|l|}{ Smoke alarm } & \multirow[b]{2}{*}{$O R(95 \% C I)$} \\
\hline & No $(\%)$ without & No $\left({ }^{o}\right)$ with & \\
\hline $\begin{array}{l}\text { Age of respondent } \\
16-24 \\
25-34 \\
35-54 \\
55-74 \\
75+\end{array}$ & $\begin{array}{l}108(29) \\
192(25) \\
320(25) \\
363(33) \\
171(36)\end{array}$ & $\begin{array}{l}266(71) \\
589(75) \\
949(75) \\
750(67) \\
303(64)\end{array}$ & $\begin{array}{l}1.25(0.94 \text { to } 1.66) \\
1.00 \\
1.03(0.84 \text { to } 1.28) \\
1.48(1.20 \text { to } 1.83) \\
1.73(1.34 \text { to } 2.24)\end{array}$ \\
\hline $\begin{array}{l}\text { Household with child } \\
\text { Yes } \\
\text { No }\end{array}$ & $\begin{array}{l}\text { en } \\
240(20) \\
915(33)\end{array}$ & $\begin{array}{r}978(80) \\
1879(67)\end{array}$ & $\begin{array}{l}0.50(0.43 \text { to } 0.59) \\
1.00\end{array}$ \\
\hline $\begin{array}{l}\text { Housing tenure } \\
\text { Owned } \\
\text { Rented (public }{ }^{\star} \text { ) } \\
\text { Rented (private } \dagger \text { ) }\end{array}$ & $\begin{array}{l}761(28) \\
268(27) \\
122(45)\end{array}$ & $\begin{array}{r}1984(72) \\
714(73) \\
152(56)\end{array}$ & $\begin{array}{l}1.00 \\
0.98(0.83 \text { to } 1.16) \\
2.09(1.61 \text { to } 2.71)\end{array}$ \\
\hline $\begin{array}{l}\text { Car ownership } \\
\text { None } \\
\text { One car } \\
\text { Two or more cars }\end{array}$ & $\begin{array}{l}447(37) \\
496(27) \\
212(22)\end{array}$ & $\begin{array}{r}767(63) \\
1319(73) \\
771(78)\end{array}$ & $\begin{array}{l}2.12(1.74 \text { to } 2.58) \\
1.37(1.13 \text { to } 1.65) \\
1.00\end{array}$ \\
\hline
\end{tabular}

^Local authority, housing association, employer.

†Private landlord.

Table 2 Household predictors of smoke alarm non-ownership (families with children)

\begin{tabular}{|c|c|c|c|}
\hline \multirow[b]{2}{*}{ Variable } & \multicolumn{2}{|l|}{ Smoke alarm } & \multirow[b]{2}{*}{ OR $(95 \% C I)$} \\
\hline & No (\%) without & No $(\%)$ with & \\
\hline $\begin{array}{l}\text { Age of respondent } \\
16-24 \\
25-34 \\
35+\end{array}$ & $\begin{array}{r}38(28) \\
81(18) \\
120(19)\end{array}$ & $\begin{array}{r}96(72) \\
371(82) \\
511(81)\end{array}$ & $\begin{array}{l}1.81(1.13 \text { to } 2.90) \\
1.00 \\
1.08(0.78 \text { to } 1.49)\end{array}$ \\
\hline $\begin{array}{l}\text { Lone parent } \\
\text { Yes } \\
\text { No }\end{array}$ & $\begin{array}{r}60(26) \\
168(18)\end{array}$ & $\begin{array}{l}174(74) \\
774(82)\end{array}$ & $\begin{array}{l}1.59(1.12 \text { to } 2 \cdot 26) \\
1.00\end{array}$ \\
\hline $\begin{array}{l}\text { Housing tenure } \\
\text { Owned } \\
\text { Rented (public }{ }^{\star} \text { ) } \\
\text { Rented (private } \dagger \text { ) }\end{array}$ & $\begin{array}{r}137(17) \\
70(20) \\
32(41)\end{array}$ & $\begin{array}{r}653(83) \\
276(77) \\
47(60)\end{array}$ & $\begin{array}{l}1.00 \\
1.21(0.87 \text { to } 1.69) \\
3.25(1.94 \text { to } 5.42)\end{array}$ \\
\hline $\begin{array}{l}\text { Car ownership } \\
\text { None } \\
\text { One car } \\
\text { Two or more cars }\end{array}$ & $\begin{array}{r}72(25) \\
101(19) \\
67(17)\end{array}$ & $\begin{array}{l}218(75) \\
440(81) \\
320(83)\end{array}$ & $\begin{array}{l}1.58 \cdot(1.07 \text { to } 2.33) \\
1.10(0.77 \text { to } 1.56) \\
1.00\end{array}$ \\
\hline
\end{tabular}

^Local authority, housing association, employer.

+ Private landlord

Table 3 Household correlates of smoke alarm non-ownership (multivariate)

\begin{tabular}{|c|c|c|}
\hline Variable & $\begin{array}{l}\text { OR }(95 \% \text { CI }) \\
\text { (all households) }\end{array}$ & $\begin{array}{l}\text { OR }\left(95^{\circ} \text { o CI) }\right. \\
\text { (families with children) }\end{array}$ \\
\hline $\begin{array}{l}\text { Age of respondent } \\
16-24 \\
25-34 \\
35+\end{array}$ & $\begin{array}{l}1.03(0.78 \text { to } 1.37) \\
1.00 \\
1.06(0.87 \text { to } 1.29)\end{array}$ & $\begin{array}{l}1.65(1.03 \text { to } 2.63) \\
1.00 \\
1.26(0.90 \text { to } 1.76)\end{array}$ \\
\hline $\begin{array}{l}\text { Household with children } \\
\text { Yes } \\
\text { No }\end{array}$ & $\begin{array}{l}0.54(0.46 \text { to } 0.65) \\
1.00\end{array}$ & $\begin{array}{l}\text { Lone parent families } \\
1.27(0.84 \text { to } 1.91) \\
1.00\end{array}$ \\
\hline $\begin{array}{l}\text { Housing tenure } \\
\text { Owned } \\
\text { Rented (public }{ }^{\star} \text { ) } \\
\text { Rented (private } \dagger \text { ) }\end{array}$ & $\begin{array}{l}1.00 \\
0.77(0.64 \text { to } 0.93) \\
1.82(1.40 \text { to } 2.38)\end{array}$ & $\begin{array}{l}1.00 \\
1.02(0.69 \text { to } 1.52) \\
2.68(1.56 \text { to } 4.60)\end{array}$ \\
\hline $\begin{array}{l}\text { Car ownership } \\
\text { None } \\
\text { One or more }\end{array}$ & $\begin{array}{l}1.76(1.49 \text { to } 2.08) \\
1.00\end{array}$ & $\begin{array}{l}1.21(0.80 \text { to } 1.84) \\
1.00\end{array}$ \\
\hline
\end{tabular}

^Local authority, housing association, employer.

+ Private landlord. smoke alarm $(\mathrm{OR}=2 \cdot 09,95 \%$ CI $1 \cdot 61$ to $2 \cdot 71)$ than owner occupied homes. The sociodemographic correlate of alarm use among families with children under 15 years are shown in table 2. Once again, in comparison with families living in owner occupied households, families in private landlord rental accommodation were significantly less likely to have a smoke alarm (OR $=3.25,95 \%$ CI 1.94 to $5 \cdot 42$ ).

Twenty seven per cent of respondents reported having heard of National Fire Safety Week. Households in which the respondent had heard of National Fire Safety Week were significantly more likely to have a smoke alarm (OR $=0.73,95 \%$ CI 0.62 to $0 \cdot 86$ ). Eighty one per cent of respondents had heard of the TV smoke alarm advertising campaign and these households were also significantly more likely to have an alarm $(\mathrm{OR}=0.69,95 \% \mathrm{CI} 0.58$ to $0 \cdot 82$ ).

The results of logistic regression modelling are shown in table 3 . ORs greater than 1 indicate that smoke alarms are less likely to be present, whereas those less than 1 indicate that smoke alarms are more likely to be present in association with the factor analysed. Households with children were more likely to have a smoke detector. Two factors were significant predictors of the absence of a smoke alarm: homes rented from private landlords and not owning a car. For families with children, accommodation that was rented from a private landlord was the strongest predictor of the absence of a smoke alarm (OR $=2 \cdot 68,95 \%$ CI 1.56 to 4.60 ) after controlling for age, car ownership, and lone parenthood. In the multivariate analysis, controlling for housing tenure, car ownership, and age of respondent, there was no association between lone parenthood and the absence of a smoke alarm. The association between having heard of National Fire Safety Week or the TV smoke alarm advertising campaign, and smoke alarm use, was examined controlling for age, housing tenure, presence of children, and car ownership in a logistic regression model. The ORs were $0.75(95 \%$ CI 0.64 to 0.88$)$ for National Fire Safety Week and 0.77 (95\% CI 0.65 to 0.92$)$ for the TV campaign. When the analyses were limited to families with children, the respective ORs were $0.59(95 \% \mathrm{CI} 0.41$ to 0.83$)$ and 0.55 ( $95 \%$ CI 0.38 to 0.55$)$.

\section{Discussion}

In the UK, smoke alarm ownership has continued to increase, with $71 \%$ of households reporting the presence of one or more smoke alarms. The finding that the use of these devices is even higher $(80 \%)$ among families with children is encouraging, considering that fire risk is greater in these households. ${ }^{6}$ Families with children living in accommodation rented from a private landlord are substantially more likely to be without an alarm. Forty one per cent of households that were rented privately were without a smoke alarm, compared with $17 \%$ of owner occupied homes. The results of logistic regression modelling suggest that the lower level of alarm use by single 
parent families may be partly explained by their over-representation in this type of housing. Because a small proportion $(6 \%)$ of families with children live in private rental accommodation, strategies targeted towards increasing alarm installation in rental accommodation would have a small impact on the total prevalence of alarm use. On the other hand, results from the 1994 British Crime Survey show that the risk of fire is greatest for families living in rental accommodation, in which case it is possible that a small increase in use may be associated with a disproportionately large reduction in paediatric fire related mortality. ${ }^{6}$

Car ownership was used in the analyses as an indicator of household socioeconomic disadvantage. The finding that families without a car were significantly more likely to be without a smoke detector, suggests a socioeconomic gradient in smoke alarm use. Death rates from residential fires show a steep socioeconomic gradient, with poor children having a greatly increased risk of death. ${ }^{7}$ Taken together, these findings indicate that the families at greatest risk of fire related mortality are those least likely to have smoke detectors.

What might health professionals do to increase alarm use? Controlled evaluations show that paediatric counselling is effective in increasing smoke alarm installation. Miller et al compared alarm use in the families of 120 children seen consecutively for routine health care (control group) with alarm use by families of the next 120 children seen, who received a pamphlet, a brief educational message, and the option of buying a smoke alarm at cost price (experimental group). ${ }^{8}$ Alarm use was assessed six weeks later by a home visit ( $89 \%$ follow up). Of those who were initially without alarms, $47 \%$ of the experimental group had subsequently installed alarms compared with none of the controls. Increased alarm installation after physician counselling was also noted in a randomised controlled trial of a group burn prevention education programme, although the difference was reported as not 'significant'.' These findings, and the fact children attending hospitals are likely to represent a high risk group for residential fires, suggest that physician counselling may be a worthwhile activity.

There is also evidence that smoke alarm legislation is an effective method of increasing alarm use. McLoughlin et al compared smoke alarm use in Montgomery County, the first major jurisdiction to pass a law requiring smoke detectors in all homes, with that in a neighbouring county that had no such law. ${ }^{10}$ Five years after the law was passed, Montgomery County had a significantly lower percentage of homes that were without detctors $(6 \%$ compared with $16 \%)$. Although efforts have been made to mandate the use of alarms in homes in Britain, to date these efforts have been largely unsuccessful.

National Fire Safety Week is a week of concentrated publicity designed to promote fire safety both in the home and in the workplace. The week typically involves a combination of mass media advertising and local initiatives by fire brigades, with the aim of providing information about the danger from fire and strategies for preventing them. Particular emphasis is given in the campaign to the safety benefits of smoke alarms. The observation that households in which the respondent had heard of National Fire Safety Week and the televised smoke alarm campaign were more likely to have a smoke alarm is encouraging, but given the potential for confounding, can not be taken as proof of efficacy. The effect of both campaigns was greater for families with children, suggesting that they may be particularly responsive to fire safety education.

Smoke alarms are believe to be 'the single most effective strategy for the prevention of injury in children'. ${ }^{11}$ The results of this survey show that although alarm use has continued to increase, there is still a substantial number of households without alarms. Moreover, the households at greatest risk of fire are most likely to be without alarms. Health professionals can increase the use of smoke alarms among families with children by asking about alarm use, and counselling families about the benefits. Most importantly, health professionals can lobby government to require councils, housing associations, and private landlords to install alarms in all properties. ${ }^{12}$

The support of Ms Gillian Goddard and the Fire Statistics Section of the Home Office is gratefully acknowledged. Any opinions expressed in this paper are those of the author.

1 Bellos A. Five children are killed in house fire. Guardian 11 August 1995

2 Roberts I. Deaths of children in house fires. BMF 1995; 311:

$1381-2$.
3 Runyan CW, Bangdiwala SI, Linzer MA, Sacks JJ, Butts J Risk factors for fatal residential fires. $N$ Engl Med $\mathcal{f} 1992$; 327: 859-63.

4 Home Office. Household fires in England and Wales: information from the 1992 British Crime Survey. London: Home Office, 1992.

5 Office of Population Censuses and Surveys. The use of smoke alarms. Social Survey News. London: OPCS, 1993.

6 Home Office. Household fires in England and Wales: information from the 1994 British Crime Survey. London: Home
Office, 1994.

7 Office of Population Censuses and Surveys. Occupational mortality: childhood supplement (DS No 8). London: HMSO, 1988.

8 Miller RE, Reisinger KS, Blatter MM, Wucher F. Paediatrics counselling and subsequent use of smoke detectors. Am f Public Health 1982; 72: 392-3.

9 Thomas KA, Hassanein RS, Christophersen ER. Evaluation of group well-child care for improving burn prevention practices in the home. Pediatrics 1984; 74: 879-82.

10 McLoughlin E, Marchone M, Hanger SL, German PS Baker SP. Smoke detector legislation: its effects on owner-occupied homes. Am $\mathcal{F}$ Public Health 1985; 75: 858-62.

11 Rivara FP. Traumatic deaths of children in the United States: currently available prevention strategies. Pediatrics 1985; 75: 456-62.

12 McCabe M, Sibert J. Smoke detectors save lives. BMF 1990; 301: 982 . 